\title{
Evaluation of Fruit Removal Force of Coffee Cultivars
}

\author{
C.H. Crisosto ${ }^{1}$ \\ Hawaiian Sugar Planters' Association, 99-193 Aiea Hts. Dr., Aiea, \\ HI 96701-1057
}

\author{
M.A. Nagao \\ Hawaii Agricultural Experiment Station, University of Hawaii, 461 W. \\ Lanikaula St., Hilo, HI 96720
}

Additional index words. Coffea arabica, abscission, harvesting, ripening

Although the coffee industry in Hawaii is centered in Kona (elevation 213 to $610 \mathrm{~m}$ ), coffee plantings are currently being established on abandoned sugar cane and pineapple lands at lower elevations in other areas of the state. Large-scale plantings are anticipated with high beverage quality as an objective. For optimum beverage quality, coffee fruits are harvested when fully ripe (Goto and Fukunaga, 1985). Harvesting in Hawaii is currently accomplished by hand; however, large-scale coffee production will require mechanical harvesting (Winston, 1987].

To evaluate quality, production, and the suitability of coffee cultivars for mechanical harvesting, cultivar trials have been established at low-elevation sites used for sugar and pineapple production. Included in the trials are: 'Guatemala', the principal cultivar in Kona, 'Yellow Caturra', a major cultivar in Colombia, and 'Mundo Novo' and 'Catuai', major cultivars in Brazil. Initial yield data show that these cultivars, along with 'Progeny 502', exhibit higher yields among the 18 cultivars being evaluated (Ingamells, 1990).

Fruit removal force (FRF) is an important characteristic for evaluating the suitability of a cultivar for mechanical harvesting, since the efficiency- of harvesting devices is directly related to a lower detachment force of ripe fruits (Bukovac, 1979). There should

Received for publication 26 Mar. 1990. Journal Series no. 3475 of the Hawaii Institute of Tropical Agriculture and Human Resources. We gratefully acknowledge the Hawaiian Sugar Planters' Assn. for the field facilities and part of the economic support of this research. This research was also supported in part by the U.S. Dept. of Agriculture under CSRS Special Grant no. 87-CSRS 2-3090 and 88-34135-3604, managed by the Pacific Basin Advisory Group. The cost of publishing this paper was defrayed in part by the payment of page charges. Under postal regulations, this paper therefore must be hereby marked advertisement solely to indicate this fact.

'Present address Pomology Dept., Univ. of California, Davis, CA 95616. also be large differences in FRF between ripe and immature fruit to facilitate the selective removal of ripe fruit. The objectives of this study were to evaluate the FRF of ripe and immature fruit of several coffee cultivars and to determine diurnal fluctuations in FRF that could be exploited to facilitate mechanical harvesting.

Fruit removal force measurements in newtons $(\mathrm{N})$ were obtained from two-year-old Coffea arabica L. 'Yellow Caturra', 'Mundo Novo', 'Catuai', 'Progeny 502', and 'Guatemalan' trees. Trees were located at Kunia, Hawaii (elevation $100 \mathrm{~m}$ ), in a Kunia silty clay soil (Ustoxic Humitropepts), and kept well-irrigated for the duration of the experiment. The trees were spaced $0.9 \mathrm{~m}$ between plants and $2.6 \mathrm{~m}$ between rows. Fruit removal force of 20 ripe (exocarp completely red or yellow, depending upon cultivar) and 20 full-size green fruit was measured in the field at 0600, 0900, 1300, and $1600 \mathrm{HR}$ in Nov. 1989, by securing fruits in a collar attached to a pull scale and pulling in a direction parallel to the pedicel. At each time period during 4 sampling days, the FRF of five ripe and five green fruit on primary plagiotropic branches (Cannell, 1985) 1.2 to $1.5 \mathrm{~m}$ above ground level was measured on 10 trees of each cultivar arranged in a completely randomized design. To obtain the mean FRF for each time period, FRF for the 4 days was pooled.

Differences in FRF between ripe and green fruits between 0600 and $1600 \mathrm{HR}$ ranged from

Table 1. Fruit removal force (FRF), in N, of ripe and full-size green coffee fruit of various cultivars.

\begin{tabular}{lccc}
\hline \hline & \multicolumn{2}{c}{$\begin{array}{c}\text { Daily } \\
\text { mean FRF (N) }\end{array}$} & $\begin{array}{c}\text { Difference in } \\
\text { daily mean FRF (N) } \\
\text { (green-ripe) }\end{array}$ \\
\cline { 2 - 4 } & Ripe & Green & $7.3 \mathrm{~d}$ \\
Yellow Caturra & $5.7 \mathrm{a}$ & $13.0 \mathrm{~d}$ & $4.0 \mathrm{c}$ \\
Guatemalan & $8.0 \mathrm{~b}$ & $12.0 \mathrm{bc}$ & $4.5 \mathrm{c}$ \\
Catuai & $8.2 \mathrm{~b}$ & $12.7 \mathrm{~cd}$ & $2.4 \mathrm{~b}$ \\
Mundo Novo & $8.3 \mathrm{~b}$ & $10.7 \mathrm{a}$ & $1.1 \mathrm{a}$ \\
Progeny 502 & $10.3 \mathrm{c}$ & $11.4 \mathrm{ab}$ & \\
\hline
\end{tabular}

${ }^{2}$ Mean separation in columns by Duncan's multiple range test, $P=0.05$.

'Values are the mean FRF from 0600 to 1600 HR. suggest that morning harvesting is recom-
6.8 to $8.5 \mathrm{~N}$ for 'Yellow Caturra', 3.5 to 5.9 $\mathrm{N}$ for 'Catuai', 2.2 to $5.5 \mathrm{~N}$ for 'Guatemala', 1.4 to $3.8 \mathrm{~N}$ for 'Mundo Novo', and 0.1 to $1.8 \mathrm{~N}$ for 'Progeny 502'. Differences were larger between 0600 and $0900 \mathrm{HR}$ than between 1300 and 1600 HR for 'Guatemala', and 'Mundo Novo'.

Daily mean FRF for ripe fruits was lowest for 'Yellow Caturra' and highest for 'Progeny 502'. For green fruits, mean FRF was highest for 'Yellow Caturra' and lowest for 'Mundo Novo' (Table 1). The largest differences between daily means of ripe and green fruit were found in 'Yellow Caturra'; they were intermediate for 'Catuai' and 'Guatemala' and smallest for 'Mundo Novo' and 'Progeny 502'.

These data show that the potential for increased selectivity during mechanical harvesting appears better with 'Yellow Caturra', 'Catuai', and 'Guatemala', where larger differences in FRF between ripe and green fruits were observed than for 'Mundo Novo' and 'Progeny 502'. More pronounced differences early in the day for 'Guatemala' mended where feasible for this cultivar. The smaller differences between ripe and green fruit of 'Progeny 502' and 'Mundo Novo' may result in decreased selectivity during harvesting.

\section{Literature Cited}

Bukovac, M.J. 1979. Machine-harvest of sweet cherries: Effect of ethephon on fruit removal and quality of processed fruit. J. Amer. Sot. Hort. Sci. 104:289-294.

Cannell, M.G.R. 1985. Physiology of the coffee crop, p. 108-134. In: M.N. Clifford and K.C. Willson (eds.). Coffee botany, biochemistry and production of beans and beverage. AVI, Westport, Conn.

Goto, B.Y. and E.T. Fukunaga. 1985. Harvesting and processing for top quality coffee. Univ. of Hawaii, Hawaii Inst. Trop. Agr. and Human Resources Ext. Cir. 359.

Ingamells, J.L. 1990. Outstanding coffee cultivars. Annual Report. 1989. Expt. Sta., Hawaiian Sugar Planters' Assn. p. 71-73.

Winston, T. 1987. Arabica coffee: A newly revived industry in Queensland. Austral. Hort., Produce and Process Crops Ed. 1:10-16. 